\title{
Electricity Consumption and Economic Growth in Nigeria: A Sectoral Analysis
}

\author{
Akomolafe Kehinde John \\ Department of Economics, Afe Babalola University \\ Ado Ekiti, Nigeria \\ Tel: 234-703-737-7061Ｅ-mail: akjohn2@yahoo.com
}

Received: May 10, 2019

Accepted: June 18, 2019

Published: June 23, 2019

doi:10.5296/wjbm.v5i1.14972

URL: https://doi.org/10.5296/wjbm.v5i1.14972

\begin{abstract}
This paper examines the causality between electricity consumption and economic growth in Nigeria, with a focus on sectorial analysis. The sectors considered are manufacturing sector, agriculture sector, and the service sector. The study covers the periods from 1981 to 2014 . The study was done in a vector error correction model (VECM). The results show that the causality run from manufacturing sector to electricity consumption in long run, but a bidirectional causality in the short run, from electricity consumption to service sector output in the long run, and from electricity consumption to service sector output in long run. There is no short run causality between electricity consumption and service sector and agricultural sectors outputs. The paper concludes with the recommendation that government should be careful in implementing electricity conservation policy.
\end{abstract}

Keywords: Electricity consumption, Economic growth, Manufacturing, Agriculture, Service 


\section{Introduction}

Achieving a sustained economic growth is one of the most important macroeconomic objectives of developing nations (Ezigbo, 2012). However, no country can grow higher than its level of investments. One of the problems that has plagued investment, and consequently economic growth in Nigeria, and many African countries, is the problem of epileptic supply of electricity. Investment only thrives in a conducive environment, where the cost of investment is relatively low and stable. For an investor, the cost of investment plays important role in investment decisions. This is because it determines the return on the investment. The higher the cost of investment, the lower is the return on the investment. Hence, an investor would prefer to invest in environment that guarantees low cost of investments. Access to cheap and stable electricity plays important roles in the growth of business, and consequently, economic growth. It is difficult for business to survive in environment with, costly, unstable and erratic power supply. According to Lemma, Massa, Scott, and Willem te Velde (2016), insufficient, unreliable or costly access to power can be a binding constraint to business. Hence, electricity plays important role in attaining sustained economic growth in an economy.

Electricity affects economic growth through different channels. Every sector of the economy uses electricity directly or indirectly. A stable and affordable electricity supply will reduce cost of production. Also, it will reduce the turn-around time of business, and increases productivity of the enterprise. This will consequently increase investors' profit margins. Increase in profit will lead to increase in employment generation in the country, and ultimately leads to the growth of the economy. According to Rajkumari and Gayithri (2017), economic growth, industrialization, and urbanization are closely associated with the levels and growth of electricity consumption, because it is essential for the production and consumption activities of an economy.

In developing countries, the problem of unstable power supply has been identified as one of the major problems inhibiting economic growth. According to Lemma, Massa, Scott, and Willem te Velde (2016), over 600 million people in sub-Saharan Africa lack access to electricity, and power outages cost African countries an estimated 1-2 per cent of their GDP annually. According to Mawejje (2014), Uganda has one of the lowest electricity consumption levels in the world, estimated at 80kWh per capita in 2012.

In Nigeria, the situation is not different. Nigeria has a population of about 170 million people, with less than 8,000 MW installed capacity of electricity (Onochie, Egware, \& Eyakwanor, 2015). Out of these, about 5,000 MW are generated, with more than a quarter lost in transmission. Also, according to Central Bank of Nigeria (2015), Nigeria is ranked by World Economic Forum's Global Competitiveness Report 2014-2015 at number 141 out of 148 countries in terms of the quality of electricity supply. Zubair and Olanrewaju argued that only 40 percent of Nigerians have access to electricity, and they are majorly in urban areas. The epileptic supply of electricity has made citizens to often resort to alternative means of power like alternative power generators. This has made the Nigerian economy to be described as a generator economy (Ekpo, 2009). 


\section{Mll Macrothink}

World Journal of Business and Management

ISSN 2377-4622

2019, Vol. 5, No. 1

The implication of this on investors in the country is high operational costs and poor competitiveness. According to George and Oseni (2012), inadequate and unstable power supply is one of the problems facing industrial growth in Nigeria. Also, Iwayemi (2008) asserted that most of the country's economic woes, including its inability to industrialize, could be attributed to dismal performance of the electricity sector. Also, an average firm in Nigeria in 2007 experienced, on the average, power outage of about 8 hours for 26 times in a typical month (Oseni \& Pollit, 2013). Any policies aimed at increasing the growth of the non-oil sector of the economy must therefore focus on increasing access to electricity in the country. It is therefore important to understand the relationship between electricity consumption and economic growth.

The direction of causality between electricity consumption and economic growth has been a subject of debate in the literature since the study by Kraft and Kraft (1978) on the relationship between energy consumption and economic growth. The debate on the causality between them can be classified into four views: Growth hypothesis, the Conservation hypothesis, the Feedback hypothesis, and the Neutrality hypothesis. While Growth hypothesis holds the view that increased use of electricity brings about increased growth, Conservation hypothesis argues that increased use of electricity is a result of increased economic growth. Increased growth would mean increased income for households, increased consumption, higher growth of industry, increased urbanization rate, higher demand for infrastructural facilities, and ultimately, increased demand for electricity. Apart from this, the Feedback hypothesis argues that the direction of causality between them is bidirectional. This means that increased electricity usage may lead to economic growth, while economic growth may, at the same time, leads to more electricity usage. In the extreme case, Neutrality hypothesis holds the view that there is no causality between them.

Understanding the direction of causality between electricity consumption and economic growth will help policy makers make informed decision towards implementing the ongoing electricity reform in the country. This is because if electricity does not granger cause economic growth, implementing electricity conservation policy will not have significant effect on economic growth.

\section{Review of Literature}

This section presents a review of previous studies on the causal relationship between electricity and economic growth. On developed countries, Chandran, Sharma, and Madhavan (2010) investigate the nexus between electricity consumption and economic growth in Malyasia using Autoregressive Distributed Lag (ARDL). The result shows that a short run unidirectional causality exits from electricity consumption to economic growth. Tang and Tan (2013) found a bidirectional causality between electricity consumption and economic growth both in short run and long run in Malaysia. However, in a reinvestigation of the causal relationship in the same country, Tang (2008) finds a bidirectional causality between the two variables. In China, (Shiu \& Lam, 2004; Yuan, Zhao, Yu, \& Hu, 2007) find a unidirectional Granger causality running from electricity consumption to economic growth.

In other Asian countries, Ghosh (2002) finds unidirectional causality running from economic 
growth to electricity consumption in India, Yoo (2005) finds a bi-directional causality between electricity consumption and economic growth in Korea, Ho and Siu (2007) finds unidirectional causality from electricity consumption to economic growth, Yoo and Kim (2006) find a unidirectional causality running from economic growth to electricity generation in Indonesia, and Mozumder and Marathe (2007) find unidirectional causality from per capita GDP to per capita electricity consumption in Bangladesh.

In Europe, Shahbaz, Tang, and Shabbir (2011) find a unidirectional causality from economic growth to electricity consumption in Portugal, Gurgul and Lach (2012) find a bidirectional causality between electricity consumption and economic growth in Poland, Ciarreta and Zarraga (2010) find a unidirectional linear causality running from economic growth to electricity consumption in Spain. In Greece, Polemis and Dagoumas (2013) find a bidirectional causality between electricity consumption and economic growth.

In Turkey, Aslan (2014) used ARDL approach and finds no causality between electricity consumption and economic growth in the short run, but bidirectional causality in the long run. In the same year, Nazlioglu, Kayhan, and Adiguzel (2014) used error correction model to examine the causality between the two variables in the same country and found bi-directional Granger causality exists in both the short- and the long-run. In a similar study, Aslan (2014b) introduced the effect of labour force into the relationship between electricity consumption and economic growth. The result confirms the existence of bidirectional causality between electricity consumption and GDP, but no causality between labor force and electricity consumption. Aktaş and Yilmaz (2012) also finds a bidirectional relationship between electricity consumption and economic growth in the short-run, and unidirectional causality running from economic growth to electricity consumption in the long-run.

In a similar study in Turkey, Pempetzoglou (2014) disaggregated electricity consumption into residential, commercial electricity consumption, government offices, street illumination, industrial and other activities electricity consumption with the aims of establishing the source of linearity and nonlinearity between electricity consumption and economic growth. The linear relationship shows unidirectional causality from economic growth to residential, commercial and street illumination electricity consumption, while the nonlinear relationship shows a unidirectional causality from residential and commercial electricity consumption towards economic growth. Others studies like (Acaravc, Erdogan, \& Akal, 2015; Acaravci, 2010; Acaravci \& Ozturk, 2012; Gokten \& Karatepe, 2016; and Dogan, 2015) find a unidirectional causality from electricity consumption to economic growth in Turkey.

In both South America and North America, Pao and Fu (2013) find a unidirectional causality from hydroelectric consumption to economic growth in Brazil. Also, Pao and Fu (2013b) find a unidirectional causality from non-hydroelectric renewable energy consumption to economic growth in Brazil. Bowden and Payne (2010) use Toda-Yamamoto long-run causality test and find a bidirectional causality between commercial non-renewable energy consumption and economic growth, and between residential non-renewable energy consumption and economic growth, but a unidirectional causality from residential renewable energy consumption to economic growth, and from industrial non-renewable energy consumption to economic 
growth.

In Africa, Akinlo (2009); Iyke (2015); Adebola and Opeyemi (2011); Okorie and Sylvester (2016); Akomolafe and Danladi (2014); and Orhewere and Henry (2011) find a unidirectional causality running from electricity consumption to economic growth, Akinwale, Jesuleye, and Siyanbola (2013) find a unidirectional causality from economic growth to electricity consumption. Oshota (2014); Adedokun (2015), find a bidirectional causality between electricity consumption and economic growth, while Akpan and Akpan (2012) find no causality between electricity consumption and economic growth in Nigeria.

In other African countries, Odhiambo (2009) and Ouédraogo (2010) find a bidirectional causality between electricity consumption and economic growth in South Africa and Burkina Faso respectively, Odhiambo (2009b) and Solarin (2011) find a unidirectional causality from electricity consumption to economic growth in Tanzania and Botswana respectively, Adom (2011) finds a unidirectional causality from economic growth to electricity consumption in Ghana, and Kouakou (2011) finds unidirectional causality from electricity consumption to economic growth in Cote d'Ivoire

In multi- country studies, Wolde-Rufael (2006), in a study of 12 African states, finds unidirectional causality running from real GDP per capita to electricity consumption per capita in six countries, a unidirectional causality from electricity consumption to economic growth, in three countries, and a bi-directional causality between electricity consumption and economic growth for the remaining 3 countries. Also, Yoo (2006) examine causal relationship between electricity consumption and economic growth among the Association of South East Asian Nations (ASEAN). The results show a bidirectional causality in Malaysia and Singapore, but a unidirectional causality from economic growth to electricity consumption in Indonesia and Thailand. Wolde-Rufael (2014) examines the causal relationship between electricity consumption and economic growth in transition countries, and finds unidirectional causality running from electricity consumption to economic growth in Belarus and Bulgaria; a unidirectional causality from economic growth to electricity consumption in Russia, Czech Republic, Latvia, and Lithuania, a bidirectional causality in Ukraine, while no causality in Albania, Macedonia, Moldova, Poland, Romania, Serbia, Slovak Republic and Slovenia.

In a study by Squalli (2007) on the on the causality between electricity consumption and economic growth in eleven OPEC countries, the results show growth hypothesis in five countries, conservation hypothesis in three countries, and neutrality hypothesis in the other three countries. Yoo and Kwak (2010) study the causal relationship between electricity consumption and economic growth in Argentina, Brazil, Chile, Columbia, Ecuador, Peru, and Venezuela, and find a growth hypothesis in Argentina, Brazil, Chile, Columbia, and Ecuador, and a feedback hypothesis in Venezuela.

\subsection{Gaps Identified in the Literature}

Most of the studies reviewed on the direction of causality between economic growth and electricity consumption used aggregate data of economic growth. This may give bias results because the causality will be more pronounced. Since GDP is an aggregation of various 
sectors' outputs, using the output of the sectors will give a better result since electricity consumption has a direct relationship on the sectors. This study therefore fills this gap in the literature by using aggregate data and sectorial output data, and then compare the results. The sectors are the manufacturing sector output, agriculture sector output, and services sector output.

\subsection{Electricity Situation in Nigeria}

With a population of about 180 million people, Nigeria has about 53\%, representing 95.4 million people without access to electricity. More worrisome is the fact that $10 \%$ of these people were not connected to the National grid (Energy Commission of Nigeria (ECN, 2015)). There have been some significant investment in the electricity sector to improve electricity generation in the country, but these have not brought the desired amount of power required for the growth of the economy. In 2001, a total of US\$295 million was invested in the sector, while it increased to US\$828 million in 2005, and US\$407.3 million in 2013 (Central Bank of Nigeria, 2015). The total installed capacity was $13,584 \mathrm{MW}$ as at 2015, but electricity generation in the country is between $3000 \mathrm{MW}$ and $5000 \mathrm{MW}$, while the required amount of electricity for the country as at 2015 was estimated at 31,210MW (ECN, 2015). The total electricity consumption increased from $136.3617 \mathrm{kWh}$ per capita in 2010 to $156.733 \mathrm{kWh}$ per capita in 2012. But decreased to $144.4799 \mathrm{kWh}$ per capita in 2014.

Indeed, there has been a progress in the electricity consumption in the country but this is still relatively low when compared to other countries. In Algeria, electricity consumption increased from $1231.97 \mathrm{kWh}$ per capita in 2012 to $1356.265 \mathrm{kWh}$ per capita in 2014 electricity. Similarly, electricity consumption in Egypt increased from $1550.811 \mathrm{kWh}$ per capita in 2010 to $1658.77 \mathrm{kWh}$ per capita in 2012, and decreased marginally to 1657.769 $\mathrm{kWh}$ per capita in 2014. The situation is also similar in South Africa with electricity consumption at $4198.401 \mathrm{kWh}$ per capita in 2014 (World Bank, 2017). In term of sectorial consumption, residential sector has the largest share with $80 \%$ of the total electricity consumption, with industrial and agricultural sectors account for 9 and $8 \%$ respectively (International Energy Agency (IEA), 2015). This has often resulted in high cost of production arising from the cost of back-up generators. According to Ekpo (2009), this has made the country to be referred to as a generator economy. Also, it has crippled the industrial sector in the country (Aliyu, Ramli, \& Saleh, 2013).

\section{Methodology}

\subsection{Granger Causality}

One of the breakthroughs in econometrics was given by Granger (1969) when he came up with methods of identifying causation among variables in a model. This is different from correlation. Unlike correlation which simply means association among variables, Granger causality refers to predictability among variables. A variable is said to Granger cause another if its past value can predict the present value of the other. Two variables can have feedback causality between them in which case they Granger cause each other. If this is so, the causality direction is said to be bidirectional. On the other, if the causality runs from one 


\section{Macrothink}

variable to the other, the directional of causality is said to be unidirectional.

In the case of electricity consumption and economic growth, if electricity consumption Granger causes economic growth, and not the other way round, there exists a unidirectional causality from electricity consumption to economic growth. On the other hand, if electricity consumption Granger causes economic growth and vice-versa, there exists a bidirectional causality between economic growth and electricity consumption. Since the traditional Granger causality two-step method, there have been developments in econometrics on the methods of identifying causality among variables, each applicable depending on its assumptions. These include, among others, Vector Autoregressive Models (VAR) or Vector Error Correction Model (VECM) (Oh \& Lee, 2004; Mahadevan \& Asafu-Adjaye, 2007; and Yuan, Kang, Zhao, \& Hu, 2008), Autoregressive Distributed Lag (ARDL) (Odhiambo, 2009; Ozturk \& Acaravci, 2010; and Liu, 2009), and Toda and Yamamoto causality test (Tsani, 2010; Wolde-Rufael, 2006; and Wolde-Rufael, 2005).

In this paper, the causality was examined in a Vector Error Correction Model (VECM). A Vector Autoregressive Models (VAR) is a model in which each variable is modeled as a linear function of past lags of itself and past lags of the other variables. All the variables in the model are assumed endogenous, and this helps to avoid the problem of endogenity that is common in econometric models.

\subsection{Model Specification}

The bivariate VECM models used in this paper are specified below:

- Economic Growth Model

$$
\begin{aligned}
& \Delta I G D P_{t}=\beta_{0}+\sum_{i=1}^{k} \beta_{1 i} \Delta I G D P_{t-i}+\sum_{i=1}^{k} \beta_{2 i} \Delta I E L E C T_{t-i}+\theta_{1} E C T_{t-1}+\varepsilon_{1 t} \\
& \triangle I E L E C T_{t}=\alpha_{0}+\sum_{i=1}^{k} a_{1 i} \Delta I G D P_{t-i}+\sum_{i=1}^{k} \alpha_{2 i} \Delta I E L E C T_{t-i}+\theta_{2} E C T_{t-1}+\varepsilon_{2 t}
\end{aligned}
$$

- Sectors' Model

- Manufacturing Sector Model

$$
\begin{gathered}
\triangle M M A N_{t}=\delta_{0}+\sum_{i=1}^{k} \delta_{a i} \Delta M A N_{t-i}+\sum_{i=1}^{k} \delta_{4 i} \Delta L E L E C T_{t-i}+\mu_{a} E C T_{t-1}+\varepsilon_{a t} \\
\triangle M E L E C T_{t}=\gamma_{0}+\sum_{i=1}^{k} \gamma_{a i} \Delta M A N_{t-i}+\sum_{i=1}^{k} \gamma_{4 i} \Delta L E L E C T_{t-i}+\mu_{4} E C T_{t-1}+\varepsilon_{4 t}
\end{gathered}
$$

\section{- Agriculture Sector Model}

$$
\begin{aligned}
& \Delta A A G I C_{t}=\varphi_{0}+\sum_{i=1}^{k} \varphi_{5 i} \Delta I A G R I C_{t-1}+\sum_{i=1}^{k} \varphi_{6 i} \Delta U E L E C T_{t-i}+\rho_{5} E C T_{t-1}+\varepsilon_{5 t} \ldots \\
& \triangle I E L E C T_{t}=\omega_{0}+\sum_{i=1}^{k} \omega_{5 j} \Delta U A G R I C_{t-i}+\sum_{i=1}^{k} \omega_{5 j} \Delta U E L E C T_{t-i}+\rho_{6} E C T_{t-1}+\varepsilon_{6 t}
\end{aligned}
$$


- Service Sector Model

$$
\begin{aligned}
& \triangle I S E R_{t}=\vartheta_{0}+\sum_{i=1}^{k} \vartheta_{7 i} \Delta I S E R_{t-i}+\sum_{i=1}^{k} \vartheta_{9 i} \Delta U E L E C T_{t-i}+\pi_{7} E_{7} T_{t-1}+\varepsilon_{7 t} \\
& \triangle I E L E C T_{t}=\sigma_{0}+\sum_{i=1}^{k} \sigma_{7 i} \Delta I S E R_{t-i}+\sum_{i=1}^{k} \sigma_{\mathbb{B i}} \Delta I E L E C T_{t-i}+\pi_{g} E C T_{t-1}+\varepsilon_{\mathrm{gt}}
\end{aligned}
$$

Where GDP is real gross domestic products, MAN is manufacturing sector output, SER is service sector outputs, AGRIC is Agriculture sector output, and ELECT is electricity consumption. All the variables are in their log forms.

The unit root tests were done using the Augmented Dickey-Fuller (ADF), while the co-integration test was done using the Johansen co-integration test. The paper used annual time series data from 1981 to 2014. The data were sourced from the Central Bank Statistical Bulleting (2016) and World Bank development indicators

\section{Empirical Results}

\subsection{Unit Root Test}

The unit roots were tested with assumption of Intercept, and Intercept and Trend. It is based on the optimal lag length of 8 , which was selected using Schwartz Criterion. The result is presented in Table 1. The results indicate that LGDP is non-stationary at level with the assumption of Intercept, and Intercept and Trend. However, it is stationary at first difference at $5 \%$ level of significance. The results are also similar with those of LMAN, LSER, LELEC and LAGRIC which were not stationary at level at 5\% level of significance. They were stationary after their first differences at $5 \%$ level of significance. Hence we use co-integration to test if a combination of the series could be stationary. In other word, if there is a long run relationship among them. This was done for each model. 
Table 1. Augmented Dickey-Fuller unit root test

\begin{tabular}{|c|c|c|c|c|c|}
\hline \multirow{3}{*}{ Variables } & \multicolumn{5}{|l|}{ At level } \\
\hline & \multicolumn{2}{|l|}{ Intercept } & \multicolumn{3}{|c|}{ Intercept and Trend } \\
\hline & T-Stat & Prob & T-Stat & & Prob. \\
\hline LGDP & -1.051766 & 0.9962 & \multicolumn{2}{|l|}{$\begin{array}{r}-1.983695 \\
\end{array}$} & 0.5878 \\
\hline LELEC & -2.390033 & 0.1521 & -3.389572 & \multicolumn{2}{|r|}{0.0701} \\
\hline LMAN & -1.642069 & 0.9993 & -0.668004 & & 0.9674 \\
\hline LSER & -4.354366 & 1.0000 & -1.364889 & & 0.8527 \\
\hline LAGRIC & -0.377818 & 0.9789 & -2.035062 & & 0.5613 \\
\hline \multirow[t]{3}{*}{ Variables } & \multicolumn{4}{|c|}{ At First Difference } & Remarks \\
\hline & \multicolumn{2}{|c|}{ Intercept } & \multicolumn{2}{|c|}{ Intercept and Trend } & \\
\hline & T-Stat & Prob. & T-Stat & Prob. & \\
\hline LGDP & $-3.299104 * *$ & 0.0233 & $-3.751620 * *$ & 0.0330 & $\mathrm{I}(1)$ \\
\hline LELEC & $-7.944543 * * *$ & 0.0000 & $-7.757399 * * *$ & 0.0000 & $\mathrm{I}(1)$ \\
\hline LMAN & $-5.343606 * * *$ & 0.0001 & $-6.159857 * * *$ & 0.0001 & $\mathrm{I}(1)$ \\
\hline LSER & $-3.069241 * *$ & 0.0392 & $-4.715025 * * *$ & 0.0034 & $\mathrm{I}(1)$ \\
\hline LAGRIC & $-5.559812 * * *$ & 0.0001 & $-5.564788 * * *$ & 0.0004 & $\mathrm{I}(1)$ \\
\hline
\end{tabular}

Note. $* * *$ indicates significance at $1 \%, * *$ indicates significance at $5 \%, *$ indicates significance at $10 \%$.

\subsection{Electricity Consumption and Economic Growth}

In this section, we analyze the relationship between electricity consumption and economic growth. This was done by first selecting the appropriate lag length. Based on the Akaike information criterion, Final prediction error (FPI), and Hannan-Quinn information criterion (HQ) the optimum lag considered for this model is one (1).

\subsubsection{Testing For Co-Integration}

Table 2 shows that Max-eigen test indicate at least one co-integrating eqn(s) at the $5 \%$ level. This means that a long run relationship exists between GDP and electricity consumption.

Table 2. Johansen Co-integration test

\begin{tabular}{|c|c|c|c|c|}
\hline Hypothesized & \multicolumn{4}{|c|}{ Trace } \\
\hline & Eigenvalue & Statistic & $5 \%$ Critical Value & Prob.** \\
\hline None * & None * & 0.339213 & 16.83314 & 12.32090 \\
\hline At most 1 & At most 1 & 0.120746 & 3.989108 & 4.129906 \\
\hline $\begin{array}{l}\text { Hypothesized } \\
\text { No of CE(s) }\end{array}$ & \multicolumn{4}{|c|}{ Max-Eigen } \\
\hline & Eigenvalue & Statistic & $5 \%$ Critical Value & Prob.** \\
\hline None * & 0.339213 & $12.84403 * *$ & 11.22480 & 0.0258 \\
\hline At most 1 & 0.120746 & 3.989108 & 4.129906 & 0.0543 \\
\hline
\end{tabular}

Note. $*$ denotes significant at $1 \%$ significance levels, denotes significant at $5 \%$ significance levels. 


\subsubsection{Causality Test Based on VECM}

The interest in this section is to examine the causality between economic growth and electricity consumption. The existence of co-integration between economic growth and electricity consumption leads to the investigation of the causality relationships between the variables by applying the VECM granger causality framework. When variables are co-integrated, at least one or all of the error correction terms should be negative and statistically significant in the short-run model indicating convergence of the variables in the long run (Mawejje \& Mawejje, 2016). The long run causality is indicated by the significance of the coefficient of ECT using t-statistic. The short run causality is examined using the VEC Granger Causality/Block Exogeneity Wald Tests.

\subsubsection{Long run Causality Test Based on VECM}

Table 3 shows that the error correction term for co-integrating equation with gross domestic product (GDP) as a dependent variable is negative and significant at one percent, implying that there exists a strong long run causality running from electricity consumption to economic growth (GDP). The coefficient of error correction term with electricity consumption as a dependent variable was observed to be insignificant and positive, implying that no existence of long run causality was observed from gross domestic product (LGDP) to electricity consumption. We therefore conclude that there is a unidirectional causality from electricity consumption to economic growth in the long run.

Table 3. Long run causality test based on VECM

\begin{tabular}{|l|l|l|l|l|l|}
\hline Causality & ECM & $\begin{array}{l}\text { Standard } \\
\text { Error }\end{array}$ & T-Statistic & Probability & Result \\
\hline $\begin{array}{l}\text { Long Run Causality } \\
\text { from LELE to LGDP }\end{array}$ & -0.043513 & 0.012847 & $-3.387053^{* * *}$ & 0.0023 & $\begin{array}{l}\text { Causality } \\
\text { Exists }\end{array}$ \\
\hline $\begin{array}{l}\text { Long Run Causality } \\
\text { from LGDP to LELEC }\end{array}$ & 0.017282 & 0.042949 & 0.402386 & 0.6907 & No Causality \\
\hline
\end{tabular}

Note. $* * *$ indicates significance at $1 \%, * *$ indicates significance at $5 \%, *$ indicates significance at $10 \%$.

\subsubsection{Short Run Causality Results}

Table 4 shows that there is no causality from electricity consumption to economic growth in the short run as shown by the non-significance of the Chi-sq in the short run. However, a weak causality exists from economic growth to electricity consumption in the short run. This is weak because it is only significant at $10 \%$. 


\section{$\triangle$ Macrothink}

Table 4. VEC Granger Causality/Block Exogeneity Wald Tests

\begin{tabular}{|l|c|c|c|}
\hline Causality & Chi-sq & Probability & Result \\
\hline Short Run Causality from D(LELE)to D(LGDP) & 0.346425 & 0.8410 & No Causality \\
\hline Short Run Causality from D(LGDP) to D(LELEC) & $4.997197 *$ & 0.0822 & Weak Causality \\
\hline
\end{tabular}

Note. $* * *$ indicates significance at $1 \%, * *$ indicates significance at $5 \%, *$ indicates significance at $10 \%$.

\subsubsection{Diagnostic Checks}

In order for the results to be reliable for policy purposes, the assumption of the model must be validated. This was done through diagnostics checks conducted in this work. They include White heteroscedasticity test with no cross terms, Jarque-Bera's normality test, and the serial correlation test which was tested using the Langrage multiplier (LM) test. The Diagnostic test results are shown in Table 5. The null hypothesis for the White heteroscedasticity test is that there is no heteroscedasticity. From the P-value of Chi-square, the null hypothesis cannot be rejected. This means that there is no heteroscedasticity in the model. Also, the null hypothesis of the Jacque-bera is that the error term is normally distributed. The P-value also shows that the null hypothesis cannot be rejected. The same result for LM autocorrelation test, which shows that the null hypothesis cannot be rejected; this means that there is no autocorrelation in the model.

Table 5. Diagnostics checks

\begin{tabular}{|l|l|c|c|}
\hline TEST & Null Hypothesis & T-Statistic & Probability \\
\hline White (Chi-sq.) & No conditional heteroscedasticity & 63.39241 & 0.3577 \\
\hline Jarque-Bera & There is normal distribution & 3.603762 & 0.4623 \\
\hline Langrage Multiplier (LM) & No Serial Correlation & 6.875112 & 0.1426 \\
\hline
\end{tabular}

Note. $* * *$ indicates significance at $1 \%, * *$ indicates significance at $5 \%, *$ indicates significance at $10 \%$.

\subsection{Sectorial Output and Electricity Consumption}

In this section, we examine the causality between sectorial outputs and electricity consumption. The sectors examined are service sector, manufacturing sector, and agricultural sector. We first establish the existence of long run relationship among the variables using Johansen co-integration test, before the long-run and short-run dynamic causality relationships between output in the different sectors and electricity consumption.

\subsubsection{Co-Integration Tests}

The Johansen approach is sensitive to the lag length criteria. For this matter, the 


\section{Al Macrothink}

World Journal of Business and Management

ISSN 2377-4622

2019, Vol. 5, No. 1

co-integration tests were estimated with a lag length of 1 . Table 6 shows that the result of the co-integration test for each model. In each model, both the Trace test and Max-Eigen test reveals at least one co-integrating equation. Based on the Trace test and Max-Eigen test, we conclude that there is long run relationships between the variables in each model

Table 6. Johansen Co-integration test

\begin{tabular}{|c|c|c|c|c|c|c|c|c|}
\hline \multirow{2}{*}{$\begin{array}{l}\text { Hypoth } \\
\text { CE No } \\
\end{array}$} & \multicolumn{4}{|c|}{ Trace } & \multicolumn{4}{|c|}{ Max-Eigen } \\
\hline & Eigenv & Statistic & $\begin{array}{c}5 \% \text { Critical } \\
\text { Value }\end{array}$ & Prob.** & Eigenvalue & Statistic & $\begin{array}{c}5 \% \text { Critical } \\
\text { Value }\end{array}$ & Prob.** \\
\hline \multicolumn{9}{|c|}{ Manufacturing Sector } \\
\hline None $*$ & 0.459857 & 19.89194 & $15.49471 * *$ & 0.0102 & 0.459857 & $19.70946^{* * *}$ & 14.26460 & 0.0062 \\
\hline At most 1 & 0.005686 & 0.182478 & 3.841466 & 0.6692 & 0.005686 & 0.182478 & 3.841466 & 0.6692 \\
\hline \multicolumn{9}{|c|}{ Agricultural Sector } \\
\hline None * & 0.409676 & 21.90253 & $20.26184 * *$ & 0.0295 & 0.409676 & $16.86670 * *$ & 15.89210 & 0.0351 \\
\hline At most 1 & 0.145612 & 5.035834 & 9.164546 & 0.2795 & 0.145612 & 5.035834 & 9.164546 & 0.2795 \\
\hline \multicolumn{9}{|c|}{ Service Sector } \\
\hline None * & 0.268155 & $13.55099 * *$ & 12.32090 & 0.0310 & 0.268155 & 9.989974 & 11.22480 & 0.0818 \\
\hline At most 1 & 0.105313 & $3.561011 * *$ & 4.129906 & 0.0702 & 0.105313 & $3.561011 * *$ & 4.129906 & 0.0702 \\
\hline
\end{tabular}

Note. ${ }^{*}$ denotes significant at $1 \%$ significance levels, denotes significant at $5 \%$ significance levels.

\subsubsection{Long Run Causality between Electricity Consumption and Sectoral Output}

\subsubsection{Long Run Causality Test Based on VECM}

Table 7 shows that the error correction term for co-integrating equation with LELEC as a dependent variable is negative and significant at one percent, implying that there exists a strong long run causality running from manufacturing sector output to electricity consumption. The coefficient of error correction term with manufacturing output as a dependent variable was observed to be significant but positive, implying that no existence of long run causality from electricity consumption to manufacturing sector outputs. We therefore conclude that there is a unidirectional causality from manufacturing sector outputs to electricity consumption in the long run.

Also, the error correction term for co-integrating equation with LELEC as a dependent variable is negative but not significant implying that there is no causality running from service sector to electricity consumption. The coefficient of error correction term with service sector as a dependent variable was observed to be significant and negative showing that long run causality exists from electricity consumption to service sector output. A similar result was observed between agricultural output and electricity consumption, with the causality running from electricity consumption to agricultural output and not the other way round. 
Table 7. Long run causality between electricity consumption and sectoral outputs based on VECM

\begin{tabular}{|l|c|c|c|c|c|}
\hline Causality & ECM & Standard Error & T-Statistic & Probability & Result \\
\hline $\begin{array}{l}\text { Long Run Causality from } \\
\text { LELEC to LMAN }\end{array}$ & 0.373194 & 0.144439 & $2.583754 * *$ & 0.0153 & $\begin{array}{c}\text { NO } \\
\text { Causality }\end{array}$ \\
\hline $\begin{array}{l}\text { Long Run Causality from } \\
\text { LMAN to LELEC }\end{array}$ & -0.405254 & 0.152022 & $-2.665764 * *$ & 0.0126 & $\begin{array}{c}\text { Causality } \\
\text { Exists }\end{array}$ \\
\hline $\begin{array}{l}\text { Long Run Causality from } \\
\text { LELEC to LSERV }\end{array}$ & -0.064453 & 0.019869 & $-3.243900^{* * *}$ & 0.0030 & $\begin{array}{c}\text { Causality } \\
\text { Exists }\end{array}$ \\
\hline $\begin{array}{l}\text { Long Run Causality from } \\
\text { LSERV to LELEC }\end{array}$ & -0.063409 & 0.074162 & -0.855012 & 0.3996 & $\begin{array}{c}\text { NO } \\
\text { Causality }\end{array}$ \\
\hline $\begin{array}{l}\text { Long Run Causality from } \\
\text { LELE to LAGRIC }\end{array}$ & -0.085612 & 0.026849 & $-3.188662 * * *$ & 0.0037 & $\begin{array}{c}\text { Causality } \\
\text { Exists }\end{array}$ \\
\hline $\begin{array}{l}\text { Long Run Causality from } \\
\text { LAGRIC to LELEC }\end{array}$ & 0.003447 & 0.036665 & 0.094016 & 0.9258 & $\begin{array}{c}\text { NO } \\
\text { Causality }\end{array}$ \\
\hline
\end{tabular}

Note. $* * *$ indicates significance at $1 \%, * *$ indicates significance at $5 \%, *$ indicates significance at $10 \%$.

\subsubsection{Short Run Causality Results}

The result of short run causality tests between electricity consumption and sectorial output is presented in Table 8 .It shows that there is bidirectional causality between electricity consumption and manufacturing sector in the short run. However, there is no short run causality between electricity consumption and agricultural sector output in the short run, as shown by the non-significance of the Chi-sq. This is also similar with the results obtained between service sector and electricity consumption where no causality exists in the short run.

Table 8. VEC Granger Causality/Block Exogeneity Wald Tests

\begin{tabular}{|l|c|c|c|}
\hline Causality & Chi-sq & Probability & Result \\
\hline Short Run Causality from D(LELE)to D(LMAN) & $23.38900^{* * *}$ & 0.0000 & Causality Exists \\
\hline Short Run Causality from D(LMAN) to D(LELEC) & $12.05580^{* * *}$ & 0.0005 & Causality Exists \\
\hline Short Run Causality from D(LELE)to D(LAGRIC) & 0.856471 & 0.6517 & No Causality \\
\hline $\begin{array}{l}\text { Short Run Causality from D(LAGRIC) to } \\
\text { D(LELEC) }\end{array}$ & 4.192288 & 0.1229 & No Causality \\
\hline Short Run Causality from D(LELE)to D(LSERV) & 1.220060 & 0.2693 & No Causality \\
\hline Short Run Causality from D(LSERV) to D(LELEC) & 0.008868 & 0.9250 & No Causality \\
\hline
\end{tabular}

Note. $* * *$ indicates significance at $1 \%, * *$ indicates significance at $5 \%, *$ indicates significance at $10 \%$. 


\subsubsection{Diagnostic Checks}

The reliability of the result of the models was further confirmed through diagnostics checks. They include White heteroscedasticity test, Jarque-Bera's normality test, and the serial correlation test which was tested using the Langrage multiplier (LM) test. The Diagnostic test results are shown in Table 9. The result shows that that there is no heteroscedasticity in the models. This is given by the value of the white heteroscedasticty test. Also, the result of the LM autocorrelation test shows that the null hypothesis cannot be rejected in each model; in other word, that there is no autocorrelation in the models. The Jaque-bera statistics also show a normal distribution.

Table 9. Diagnostics checks

\begin{tabular}{|l|c|c|c|c|c|c|}
\hline TEST & \multicolumn{2}{|c|}{ Agric Sector } & \multicolumn{2}{c|}{ Service Sector } & \multicolumn{2}{c|}{ Manufacturing Sector } \\
\hline & T-Statistic & Probability & T-Statistic & Probability & T-Statistic & Probability \\
\hline White (Chi-sq.) & 27.99575 & 0.5707 & 13.53584 & $0.7588 ;$ & 39.73365 & 0.0543 \\
\hline Jarque-Bera & 3.470065 & 0.1764 & 0.698261 & 0.9515 & 3.098525 & 0.5415 \\
\hline Langrage Multiplier & 3.752946 & 0.4405 & 6.448094 & 0.1681 & 7.716614 & 0.1025 \\
\hline
\end{tabular}

Note. $* * *$ indicates significance at $1 \%, * *$ indicates significance at $5 \%, *$ indicates significance at $10 \%$.

\section{Summary and Conclusion}

\subsection{Summary of the Study}

This paper examines the direction of causality between electricity consumption and economic activities in Nigeria. The sectors are the manufacturing sector, service sector, and the agricultural sector. The findings of this study show that electricity consumption granger causes economic growth in both short run and long run, economic growth granger causes electricity consumption only in short run. Also, there is unidirectional a causality from manufacturing output to electricity consumption in short run and long run, there is unidirectional causality from electricity consumption to service sector output in short run and long run. There is unidirectional causality from electricity consumption to service sector output in short run and long run. There is no short run causality between electricity consumption and service sector and agricultural sectors outputs

\subsection{Conclusion}

These results suggest that current efforts to improve electricity generation will accelerate growth in Nigeria by facilitating sectors growth. Moreover, results suggest electricity conservation policies can be applied in the services sector without hurting growth of the sector. Based on the major findings of this study, undertaking electricity conservation policy may not be in the interest of the country as it may impede the growth of economic activities in the country. 


\section{References}

Acaravc, A., Erdogan, S., \& Akal, G. (2015). The electricity consumption, real income, trade openness and FDI: the empirical evidence from Turkey. International Journal of Energy Economics and Policy, 5(4).

Acaravci, A. (2010). The causal relationship between electricity consumption and GDP in Turkey: Evidence from ARDL bounds testing approach. Economic Research-Ekonomska Istraživanja, 23(2), 34-43. https://doi.org/10.1080/1331677X.2010.11517410

Acaravci, A., \& Ozturk, I. (2012). Electricity consumption and economic growth nexus: A multivariate analysis for Turkey. Amfiteatru Economic, 14(31), 246.

Adebola, S. S., \& Opeyemi, B. M. (2011). Multivariate causality test on electricity consumption, capital, labour and economic growth for Nigeria. Journal of Business \& Economics, 3(1), 1.

Adedokun, A. (2015). Can electricity consumption be useful in predicting Nigerian economic growth? Evidence from error correction model. OPEC Energy Review, 39(2), 125-140. https://doi.org/10.1111/opec.12042

Adom, P. K. (2011). Electricity consumption-economic growth nexus: The Ghanaian case. International Journal of Energy Economics and Policy, 1(1), 18.

Akinlo, A. E. (2009). Electricity consumption and economic growth in Nigeria: Evidence from cointegration and co-feature analysis. Journal of Policy Modeling, 31(5), 681-693. https://doi.org/10.1016/j.jpolmod.2009.03.004

Akinwale, Y., Jesuleye, O., \& Siyanbola, W. (2013). Empirical analysis of the causal relationship between electricity consumption and economic growth in Nigeria. British Journal of Economics, Management and Trade, 3(3), 277-295. https://doi.org/10.9734/BJEMT/2013/4423

Akomolafe, K. J., \& Danladi, J. (2014). Electricity Consumption and Economic Growth in Nigeria: A Multivariate Investigation. International Journal of Economics, Finance and Management, (4), 177-182.

Akpan, U. F. (2012). Electricity consumption, carbon emissions and economic growth in Nigeria. International Journal of Energy Economics and Policy, 2(4), 292.

Aktaş, C., \& Yilmaz, V. (2012). Causal relationship between electricity consumption and economic growth in Turkey. Uluslararası Yönetim İktisat ve Işsletme Dergisi, 4(8), 45-54.

Aslan, A. (2014). Causality between electricity consumption and economic growth in Turkey: An ARDL bounds testing approach. Energy Sources, Part B: Economics, Planning, and Policy, 9(1), 25-31. https://doi.org/10.1080/15567241003681882

Aslan, A. (2014b). Electricity consumption, labor force and GDP in Turkey: Evidence from multivariate Granger causality. Energy Sources, Part B: Economics, Planning, and Policy, 9(2), 174-182. https://doi.org/10.1080/15567241003699470 
Bowden, N., \& Payne, J. E. (2010). Sectoral analysis of the causal relationship between renewable and non-renewable energy consumption and real output in the US. Energy Sources, Part B: Economics, Planning, and Policy, 5(4), 400-408. https://doi.org/10.1080/15567240802534250

Central Bank of Nigeria. (2015). Central Bank of Nigeria Annual Report, Abuja.

Central Bank of Nigeria. (2016). Annual Statistical Bulletin. Retrieved from https://www.techparagon.com/cbn-statistical-bulletin/

Chandran, V. G. R., Sharma, S., \& Madhavan, K. (2010). Electricity consumption-growth nexus: The case of Malaysia. Energy Policy, 38(1), 606-612. https://doi.org/10.1016/j.enpol.2009.10.013

Ciarreta, A., \& Zarraga, A. (2010). Electricity consumption and economic growth in Spain. Applied Economics Letters, 17(14), 1417-1421. https://doi.org/10.1080/13504850903018689

Dogan, E. (2015). The relationship between economic growth and electricity consumption from renewable and non-renewable sources: A study of Turkey. Renewable and Sustainable Energy Reviews, 52, 534-546. https://doi.org/10.1016/j.rser.2015.07.130

Energy Commission of Nigeria. (2015). Energy Commission of Nigeria Puts 2015 Power Need at 31,240MW. Retrieved from http://www.energy.gov.ng/index.php?option=com_content \&view=article \&id=121\%3Acommi ssion-puts-2015-power-need-at-31240mw-\&catid=1\%3Alatest-news \&Itemid=85

Ghosh, S. (2002). Electricity consumption and economic growth in India. Energy Policy, 30(2), 125-129. https://doi.org/10.1016/S0301-4215(01)00078-7

Gokten, S., \& Karatepe, S. (2016). Electricity consumption and economic growth: A causality analysis for Turkey in the frame of import-based energy consumption and current account deficit. Energy Sources, Part B: Economics, Planning, and Policy, 11(4), 385-389. https://doi.org/10.1080/15567249.2012.666332

Granger, C. W. (1969). Investigating causal relations by econometric models and cross-spectral methods. Econometrica: Journal of the Econometric Society, 424-438. https://doi.org/10.2307/1912791

Gurgul, H., \& Lach, Ł. (2012). The electricity consumption versus economic growth of the Polish economy. Energy Economics, 34(2), 500-510. https://doi.org/10.1016/j.eneco.2011.10.017

Ho, C. Y., \& Siu, K. W. (2007). A dynamic equilibrium of electricity consumption and GDP in Hong Kong: an empirical investigation. Energy Policy, 35(4), 2507-2513. https://doi.org/10.1016/j.enpol.2006.09.018

International Energy Agency (IEA). (2015). Electricity consumption by sector in Nigeria (1990- 2012). Retrieved from http://www.iea.org/statistics/statisticssearch/report/?country

Iyke, B. N. (2015). Electricity consumption and economic growth in Nigeria: A revisit of the 
energy-growth debate. Energy Economics, 51, 166-176. https://doi.org/10.1016/j.eneco.2015.05.024

Kouakou, A. K. (2011). Economic growth and electricity consumption in Cote d'Ivoire: Evidence from time series analysis. Energy Policy, 39(6), 3638-3644. https://doi.org/10.1016/j.enpol.2011.03.069

Liu, Y. (2009). Exploring the relationship between urbanization and energy consumption in China using ARDL (autoregressive distributed lag) and FDM (factor decomposition model). Energy, 34(11), 1846-1854. https://doi.org/10.1016/j.energy.2009.07.029

Mahadevan, R., \& Asafu-Adjaye, J. (2007). Energy consumption, economic growth and prices: A reassessment using panel VECM for developed and developing countries. Energy Policy, 35(4), 2481-2490. https://doi.org/10.1016/j.enpol.2006.08.019

Mozumder, P., \& Marathe, A. (2007). Causality relationship between electricity consumption and GDP in Bangladesh. Energy Policy, 35(1), 395-402. https://doi.org/10.1016/j.enpol.2005.11.033

Nazlioglu, S., Kayhan, S., \& Adiguzel, U. (2014). Electricity consumption and economic growth in Turkey: Cointegration, linear and nonlinear Granger causality. Energy Sources, Part B: Economics, Planning, and Policy, 9(4), 315-324. https://doi.org/10.1080/15567249.2010.495970

Odhiambo, N. M. (2009). Electricity consumption and economic growth in South Africa: A trivariate causality test. Energy Economics, 31(5), 635-640. https://doi.org/10.1016/j.eneco.2009.01.005

Odhiambo, N. M. (2009b). Energy consumption and economic growth nexus in Tanzania: An ARDL bounds testing approach. Energy Policy, 37(2), 617-622. https://doi.org/10.1016/j.enpol.2008.09.077

Oh, W., \& Lee, K. (2004). Causal relationship between energy consumption and GDP revisited: The case of Korea 1970-1999. Energy Economics, 26(1), 51-59. https://doi.org/10.1016/S0140-9883(03)00030-6

Okorie, D. I., \& Sylvester, M. A. (2016). Electricity Consumption and Economic Growth: The Nigerian Case. International Journal of Current Research, 8(12).

Orhewere, B., \& Henry, M. (2011). Energy consumption and economic growth in Nigeria. Journal of Research in National Development, 9(1), 153-165.

Oshota, S. O. (2014). Electricity consumption and economic growth in Nigeria: Evidence from Bounds test. The Empirical Econometrics and Quantitative Economics Letters, 3(4), 66-77.

Ouédraogo, I. M. (2010). Electricity consumption and economic growth in Burkina Faso: A cointegration analysis. Energy Economics, 32(3), 524-531. https://doi.org/10.1016/j.eneco.2009.08.011 
Ozturk, I., \& Acaravci, A. (2010). The causal relationship between energy consumption and GDP in Albania, Bulgaria, Hungary and Romania: Evidence from ARDL bound testing approach. Applied Energy, 87(6), 1938-1943. https://doi.org/10.1016/j.apenergy.2009.10.010

Pao, H. T., \& Fu, H. C. (2013). The causal relationship between energy resources and economic growth in Brazil. Energy Policy, 61, 793-801. https://doi.org/10.1016/j.enpol.2013.06.113

Pao, H. T., \& Fu, H. C. (2013b). Renewable energy, non-renewable energy and economic growth in Brazil. Renewable and Sustainable Energy Reviews, 25, 381-392. https://doi.org/10.1016/j.rser.2013.05.004

Pempetzoglou, M. (2014). Electricity consumption and economic growth: A linear and nonlinear causality investigation for Turkey. International Journal of Energy Economics and Policy, 4(2), 263.

Polemis, M. L., \& Dagoumas, A. S. (2013). The electricity consumption and economic growth nexus: Evidence from Greece. Energy Policy, 62, 798-808. https://doi.org/10.1016/j.enpol.2013.06.086

Shahbaz, M., Tang, C. F., \& Shabbir, M. S. (2011). Electricity consumption and economic growth nexus in Portugal using cointegration and causality approaches. Energy Policy, 39(6), 3529-3536. https://doi.org/10.1016/j.enpol.2011.03.052

Shiu, A., \& Lam, P. L. (2004). Electricity consumption and economic growth in China. Energy policy, 32(1), 47-54. https://doi.org/10.1016/S0301-4215(02)00250-1

Solarin, S. A. (2011). Electricity consumption and economic growth: Trivariate investigation in Botswana with capital formation. International Journal of Energy Economics and Policy, 1(2), 32.

Squalli, J. (2007). Electricity consumption and economic growth: Bounds and causality analyses of OPEC members. Energy Economics, 29(6), 1192-1205. https://doi.org/10.1016/j.eneco.2006.10.001

Tang, C. F. (2008). A re-examination of the relationship between electricity consumption and economic growth in Malaysia. Energy policy, 36(8), 3077-3085. https://doi.org/10.1016/j.enpol.2008.04.026

Tang, C. F., \& Tan, E. C. (2013). Exploring the nexus of electricity consumption, economic growth, energy prices and technology innovation in Malaysia. Applied Energy, 104, 297-305. https://doi.org/10.1016/j.apenergy.2012.10.061

Tsani, S. Z. (2010). Energy consumption and economic growth: A causality analysis for Greece. Energy Economics, 32(3), 582-590. https://doi.org/10.1016/j.eneco.2009.09.007

Wolde-Rufael, Y. (2006). Electricity consumption and economic growth: A time series experience for 17 African countries. Energy policy, 34(10), 1106-1114. https://doi.org/10.1016/j.enpol.2004.10.008 


\section{Macrothink}

World Journal of Business and Management

ISSN 2377-4622

2019, Vol. 5, No. 1

Wolde-Rufael, Y. (2014). Electricity consumption and economic growth in transition countries: A revisit using bootstrap panel Granger causality analysis. Energy Economics, 44, 325-330. https://doi.org/10.1016/j.eneco.2014.04.019

Wolde-Rufael, Y., (2005). Energy demand and economic growth: the African experience. Journal of Policy Modeling, 27(8), 891-903. https://doi.org/10.1016/j.jpolmod.2005.06.003

World Bank Development Indicator. Available at https://data.worldbank.org/products/wdi

Yoo, S. H. (2005). Electricity consumption and economic growth: Evidence from Korea. Energy Policy, 33(12), 1627-1632. https://doi.org/10.1016/j.enpol.2004.02.002

Yoo, S. H. (2006). The causal relationship between electricity consumption and economic growth in the ASEAN countries. Energy Policy, 34(18), 3573-3582. https://doi.org/10.1016/j.enpol.2005.07.011

Yoo, S. H., \& Kim, Y. (2006). Electricity generation and economic growth in Indonesia. Energy, 31(14), 2890-2899. https://doi.org/10.1016/j.energy.2005.11.018

Yoo, S. H., \& Kwak, S. Y. (2010). Electricity consumption and economic growth in seven South American countries. Energy Policy, 38(1), 181-188. https://doi.org/10.1016/j.enpol.2009.09.003

Yuan, J. H., Kang, J. G., Zhao, C. H., \& Hu, Z. G. (2008). Energy consumption and economic growth: Evidence from China at both aggregated and disaggregated levels. Energy Economics, 30(6), 3077-3094. https://doi.org/10.1016/j.eneco.2008.03.007

Yuan, J., Zhao, C., Yu, S., \& Hu, Z. (2007). Electricity consumption and economic growth in China: co-integration and co-feature analysis. Energy Economics, 29(6), 1179-1191. https://doi.org/10.1016/j.eneco.2006.09.005

\section{Copyright Disclaimer}

Copyright for this article is retained by the author(s), with first publication rights granted to the journal.

This is an open-access article distributed under the terms and conditions of the Creative Commons Attribution license (http://creativecommons.org/licenses/by/3.0/). 